\title{
Vielfalt and diversité: how local actors in France and Germany evaluate immigration and socio-cultural heterogeneity
}

\author{
Maria Schiller ${ }^{1 *}$ (D, Christine Lang ${ }^{2}$, Karen Schönwälder ${ }^{2}$ and Michalis Moutselos ${ }^{2}$
}

\footnotetext{
* Correspondence: schiller@essb.eur. $\mathrm{nl}$

${ }^{1}$ Erasmus University Rotterdam, Rotterdam, The Netherlands Full list of author information is available at the end of the article
}

\begin{abstract}
In both Germany and France, perceptions of immigration, diversity and their societal consequences have undergone important transformations in the past two decades. However, existing research has only partially captured such processes. The "grand narratives" of national approaches, while still influential, no longer explain contemporary realities. Further, analyses of national politics and discourses may not sufficiently reflect the realities across localities and society more broadly. While emerging in different national contexts, little is known about how diversity is actually perceived by political stakeholders at the urban level. Given the key role of immigration and diversity in current conflicts over Europe's future, it is imperative to assess present-day conceptualisations of migration-related diversity among important societal actors.

This article investigates perceptions and evaluations of socio-cultural heterogeneity by important societal actors in large cities. We contribute to existing literature by capturing an unusually broad set of actors from state and civil society. We also present data drawn from an unusually large number of cities. How influential is the perception of current society as heterogeneous, and what forms of heterogeneity are salient? And is sociocultural and migration-related heterogeneity evaluated as threatening or rather as beneficial? Based on an original data set, this study explores the shared and contested ideas, the cognitive roadmaps of state and non-state actors involved in local politics. We argue that, in both German and French cities, socio-cultural heterogeneity is nowadays widely recognized as marking cities and often positively connoted. At the same time, perceptions of the main features of diversity and of the benefits and challenges attached to it vary. We find commonalities between French and German local actors, but also clear differences. In concluding, we suggest how and why national contexts importantly shape evaluations of diversity.
\end{abstract}

Keywords: Immigration, Diversity, Perceptions, France, Germany, Local actors, Cities

\section{Introduction}

In many west European societies, perceptions of immigration and the societal transformations resulting from it have undergone significant changes in the past decades. Scholarly attention has largely focused on the departure from multiculturalism, in particular in the United Kingdom and the Netherlands (Vertovec and Wessendorf 2010),

(c) The Author(s). 2020 Open Access This article is licensed under a Creative Commons Attribution 4.0 International License, which permits use, sharing, adaptation, distribution and reproduction in any medium or format, as long as you give appropriate credit to the original author(s) and the source, provide a link to the Creative Commons licence, and indicate if changes were made. The images or other third party material in this article are included in the article's Creative Commons licence, unless indicated otherwise in a credit line to the material. If material is not included in the article's Creative Commons licence and your intended use is not permitted by statutory regulation or exceeds the permitted use, you will need to obtain permission directly from the copyright holder. To view a copy of this licence, visit http://creativecommons.org/licenses/by/4.0/. 
and the rise of what is often termed "civic integration", that is, an emphasis on the transmission of core political values and the host country language to recent immigrants (Borevi et al. 2017). Less attention has been devoted to societies that never described themselves as "multicultural". Such countries include France and Germany, that is, major European countries with large immigrant populations. In different ways, both France and Germany have traditionally emphasized the homogeneity of national societies composed of, either, republican citizens - in the case of France - or culturally similar members - in the case of Germany. In recent years, however, statements that recognize migration-related diversification have become more common. Do such statements amount to a broader shift in society from maintaining uniformity to acknowledging diversity? How influential are positive conceptualisations of socio-cultural heterogeneity, given increasing social divides, the growing influence of populist and extreme right mobilization and appeals to strengthen social cohesion?

This article investigates perceptions and evaluations of socio-cultural heterogeneity by important societal actors in France and Germany. Focusing on actors in big cities, we direct attention to the spaces where heterogeneity is most pronounced and actors may be under more pressure to position themselves. Further, an analysis of local realities can indicate to what extent scholarly assumptions about predominant perceptions, often based on national debates, can be confirmed or proven of limited validity.

In the 20 most populous cities in both France and Germany, the study examines perceptions and beliefs of composite actors (komplexe Akteure) ${ }^{1}$ involved in diversityrelated local politics. While previous studies have often concentrated on mayors and key civil servants, this study extends perspectives to a broader set of influential societal actors. We include political actors, representatives of city government and administration, organisations representing the local economy and labour market, trade unions, social welfare organisations and local bodies representing groups commonly associated with diversity. These actors help shape the local political culture, influence the ways in which issues are framed and evaluated by the general public, and take part in policy development and implementation. Altogether, our study helps widen and deepen our knowledge of urban conceptualisations of immigration and diversity.

Our study investigates perceptions and evaluations of diversity, or socio-cultural heterogeneity. We are thus not solely interested in explicit "diversity-concepts", as often employed in businesses, but in conceptions of a diversifying social reality. A framing of immigration-related change as one aspect of societal diversity places immigrationrelated differences alongside other "diversities", thus normalizing such differences. Further, it suggests a positive perception of immigration and its consequences. How common is such a perspective in two societies that have traditionally described themselves as homogeneous? Is difference sayable today, and to what extent is it appreciated or contested by local policymakers?

Before turning to the empirical evidence, the second section will briefly set out theoretical considerations and place our analysis within a context of existing scholarship. We then explain the methodology underlying this study. A fourth empirical section will be followed by a concluding discussion of the results.

${ }^{1}$ We follow a terminology suggested by $\operatorname{Scharpf}(1997$, ch. 3). The term covers corporate (korporative) actors that have some degree of formal organisation and collective actors, that is, looser umbrella structures or social movements. 


\section{Conceptualizing socio-cultural heterogeneity: theoretical considerations and state of research}

It is nowadays widely agreed among social scientists that ideas matter in policy-making (e.g. Schmidt 2008). They influence how actors define their interests and decide which problems are the most pressing and in need of solution (Bleich 2002, 1063). More generally, they provide the cognitive roadmap, appropriate categories, models, and basis of legitimacy for concrete actions. Deployed strategically, ideas can become a resource for mobilizing support and achieving policy goals (Boswell and Hampshire 2017). Differences between countries in historically established ideas or cognitive frames may lead to cross-national variation in policy outcomes (Bleich 2002).

King and Smith $(2014,958-60)$ have emphasized that it may be particularly valuable to pay attention to "critical ideational developments" or junctures, that is, shifts in how "policy issues are predominantly conceived". Immigration, with its often unpredictable dynamic and its conflict-potential, and the phenomenon of increasing socio-cultural heterogeneity, involve considerable ambiguity and uncertainty. Confronted with unfamiliar or unpredictable issues, actors may resort to established ideas or turn to new interpretations of societal realities. In the current situation of increasing socio-cultural diversification and major migration movements it therefore becomes particularly interesting to study whether actors involved in policy development and implementation resort to the old rejection of multiculturalism or develop new interpretations of societal realities acknowledging the growing socio-cultural heterogeneity.

While a considerable amount of research has focused on general public opinion on immigration and diversity (e.g. Hellwig and Sinno 2017), much less is known about the broader conceptualisation of immigration-related challenges among influential societal actors, including at the local level. Scholars have often focused on "framings", understood as ways in which actors define a particular problem by strategically selecting and emphasizing certain aspects of reality in order to communicate a specific reading of a problem (Entman 1993; Bos et al. 2016; Scholten 2011). However, a deeper understanding of the underlying perceptions of social reality, i.e. how actors make sense of current processes of diversification, is lacking. As Helbling (2014: 21) opines, we "know surprisingly little about the motivations" that lead political parties to take particular stances on immigration (but see Volkert 2017). This article contributes to filling this gap. It captures perceptions of socio-cultural heterogeneity of a range of actors who contribute to shaping public policies. It is based on data collected among important actors in large German and French cities. This is relevant as such perceptions and their connection with local policy problems arguably impact the selection of policy options.

Scholarly debates in the field of migration and integration policy-making have often centered on differences between countries and between national and local approaches (e.g. Emilsson 2015; Poppelaars and Scholten 2008; Schiller 2016). Germany and France have regularly been depicted as classic examples of non-multicultural countries that deny their socio-cultural diversity. As Alba and Foner (2014), 268-9) maintain, 'grand narratives' such as those about "national philosophies or models of immigrant integration $[. .$.$] are a persistent trope in writings about immigration". They are assumed to in-$ fluence policies and to "shape the willingness of nation states to acknowledge immigrants as ethnic minorities with distinct needs and cultural rights". At the same time, Alba and Foner are sceptical as to the explanatory power of such narratives. 
Indeed, a number of scholars have cautioned against a too unilinear view and pointed to ways in which perceptions of immigration may change over time and vary within states (Scholten 2011; Schönwälder and Triadafilopoulos 2016; Tucci 2011).

The evolution of diversity perceptions in Germany and France is interesting because they are similar regarding a traditional emphasis on maintaining the homogeneity of their citizens. In both countries, this approach came under challenge, and diversity has become a common notion. Yet, the ways in which difference is conceived and the influence of explicit "diversity" policy conceptions seem to differ. In Germany, Vielfalt began to become a key term in the mid-2000s. With Angela Merkel's Chancellorship from 2005, the politically dominant party of Germany, the CDU, moved towards an acceptance of past immigration and the resulting diversity (see, in more detail, Schönwälder and Triadafilopoulos 2016). For Conservatives and long-term opponents of multiculturalism, a commitment to Vielfalt provided an acceptable packaging for this political shift towards more openness and more liberal attitudes to a variety of life preferences. In 2006, Chancellor Merkel became patron for the Charta der Vielfalt launched by a group of leading international companies. Soon the concept of "diversity" as something to cherish was transferred from the corporate discourse to government policy and other spheres of society. In August 2007, the Grand Coalition of Conservatives and Social Democrats launched a "Diversity as Opportunity" campaign, which encouraged a view of "ethnic and cultural diversity as an economic resource of outstanding importance" (Bundesregierung 2007). By 2020, many public actors, including a large number of big cities, had signed the diversity charter to publicly demonstrate their commitment to diversity (www.charta-der-vielfalt.de/en). The notion of diversity or Vielfalt increasingly accompanies the prevalent notion of integration in immigrant policy-making in German cities (Pütz and Rodatz 2013). Nürnberg's integration policy from 2018 for instance promotes "valuing diversity" as the first of its three key tenets (City of Nürnberg 2018). And the city of Cologne, in its integration concept, presents diversity as a characteristic of the city and the recognition of diversity as prerequisite for an integration of immigrants (City of Cologne 2011). The municipal department dealing with immigrant affairs is now called "office for integration and diversity" (Amt für Integration und Vielfalt).

In France, references to the diversity of society became common earlier than in Germany. In the international arena, the French government had promoted the concept of diversité culturelle since the late 1990s, and the 2005 UNESCO convention on the protection of cultural diversity was celebrated as a French success (Glasze and Meyer 2009). If culture was seen as part of the diversité culturelle and fundamental component of cultural identities, Francophone culture and language could be protected from competition in a US- and English-language-dominated global market (Glasze and Meyer 2009, 194-5). In addition, diversité has increasingly become a concept allowing explicit reference to ethnic difference in French politics; it "make[s] sayable the question of ethnicity and 'race" (Escafré-Dublet and Simon 2009, 138). Diversité may have become for ethnic difference what laïcité has become for religious difference, a term allowing difference to be acknowledged without directly challenging 'republican' concepts (Sénac 2012, 150-5; Martínez-Ariño 2017). The notion of diversité was first used by actors demanding an increased presence of minorities in the media and political life. Since the mid-1990s, political parties and the civil service are increasingly expected to 
reflect the diversity of the French population (Sabbagh 2011, 479). Thus, in 2003, the Socialist Party emphasized the need to make candidate lists representative of the diversity of the party and the country, a demand that was repeated in the campaigns of 2010 and 2012, when an election clip introduced the newly elected MPs with the slogan "egalité, diversité et renouvellement" (Volkert 2017, 230-233; see also Escafré-Dublet and Simon 2009; Avanza 2010). Under President Sarkozy, elected in 2007, a commissioner of diversité et égalité des chances was appointed (Sénac 2012, 10). Reports on the concept of diversité and on its inclusion in the preamble of the constitution were commissioned. A Label Diversité was introduced in 2008 to encourage the adoption of diversity concepts beyond the business world (Bereni and Epstein 2015). Initially, such a label had been introduced by a business initiative. Lyon, a city that applied for the diversity label, has adopted a self-representation of the city as being "construit dans la diversité" (Flamant 2014, 546). However, contrary to what one may expect, diversity concepts may be 'colour blind' and ignore racist discrimination (Bereni et al. 2020). According to Flamant, the notion of diversité in the French cities of Nantes, Strasbourg and Lyon stands in a veritable competition with the notion of egalité and the fight against ethno-racial discriminations (Flamant 2014, 554). Focusing on local policymakers in selected areas in Paris, Lelévrier et al. (2017, 38, 43-50) show that here diversity as a term is rarely used. Like many French authors, they emphasize the persistence of traditional republican ideas about the homogeneity of the nation. In contrast, in his comparative study of the urban social policies Soziale Stadt in Germany and politique de la ville in France, Weber (2013) stresses commonalities. In both countries, he finds a positive appreciation of cultural diversity. Another recent study (Martínez-Ariño et al 2018) found that urban policies aiming to adjust the public administration and its services to a heterogeneous population and to publicly acknowledge the socio-cultural diversity of the population are indeed common in both France and Germany.

The present article offers a wide-ranging and systematic analysis of the relevance of diversity perceptions and their content in the two countries. Adding to existing case studies, we aim to capture perceptions in a large number of big cities, 20 in each country, to achieve a more valid picture of urban realities. Furthermore, based on a theoretically informed sampling strategy, we include a broad set of influential societal actors to allow insights beyond dominant state actors.

Existing literature allows different expectations. Diversity may just be a superficial label popular among managers, and traditional conceptions of the nation and its homogeneity may prove powerful in times when societal cohesion has become a major concern. Alternatively, the two societies may prove open to change and address existing heterogeneities in the population openly, or even positively. Our expectation is that the second is more likely. Respective trends in political debates have been substantial, as discussed above. As cities are known to often be amenable to heterogeneity, we expect the observed shift in frames in Germany and France to be congruent with perceptions of diversity among local actors. However, such perceptions may not be uniform throughout, but also reflect polarization at the local level. How do local actors who perceive diversification evaluate it? Do business-centered views of diversity dominate or are perceptions multi-faceted? And, finally, to what extent do local actors' perceptions reflect different ideational traditions in Germany and France? 


\section{Research design, data and methods}

Our empirical results stem from a survey of local actors in the 20 most populous cities of both France and Germany. ${ }^{2}$ The 40 cities feature a wide range of relevant actors and vary substantially in their demographic makeup and socioeconomic characteristics. The field period ran from April 2015 to March 2016. We surveyed the actors when the first signs of the "refugee crisis" became noticeable and when it enfolded. With hindsight, this period may, or may not, become evaluated as a 'critical juncture' in the ways in which two major European societies deal with immigration and diversity.

Respondents were offered a paper and an online questionnaire consisting of closedand open-ended questions regarding knowledge of and opinions about the ways in which cities are affected by local population diversity and respond to it. The survey was conducted by a team at the Max Planck Institute for the Study of Religious and Ethnic Diversity, Germany.

With our study we contribute an extended perspective to a set of actors that encompasses civil society as well as political and administrative leadership and economic actors, in accordance with urban governance theory (e.g., Stoker 2000) and its assertion that urban policy-making is increasingly marked by an interaction between public and private actors. Our sampling could not draw on a predefined population. In each city, we identified and targeted the set of composite actors ("komplexe Akteure", see note 1) involved in local politics and in diversity-relevant fields. For a detailed description of the sampling procedure see Moutselos et al (2017, 10ff).

The targeted set of respondents included political actors (leaders of main parties and council factions), city government and administration (mayors and heads of departments), organisations representing the local economy and labour market (chambers of commerce, jobcenters, etc.), selected trade unions, social welfare organisations (Caritas, Diakonie, Secours Catholique, Secours Populaire, etc.), and local bodies representing groups commonly associated with diversity (large immigrant and advocacy organisations, councils for the disabled, councils for senior citizens, and councils for immigrants, gender equality representatives). Respondents were informed that cities would be anonymized in later survey analyses. This helps reduce response bias and increases the response rate.

The data set comprises 694 completed questionnaires, representing a response rate of $45 \%$ for the German cities and $20 \%$ for the French cities. For the German cities, response rates range from $36 \%$ to $58 \%$ (between 17 and 30 respondents per city), and for the French cities from 13\% to 31\% (between 9 and 22 respondents per city). Lower response rates in France are a known problem. For any city-level analysis we excluded two French cities, because response rates were below 10\%. All other cities (20 in Germany and 18 in France) yielded a sufficient number of respondents for all questionnaire items of interest (see online Appendix Table 1).

The following sections are based on a content analysis of responses to a combination of closed- and open-ended survey questions (Weber 1990; Früh 2015). We carried out

\footnotetext{
${ }^{2}$ For more details see the technical report for the survey CityDiv. We excluded Berlin, Bremen and Hamburg because they are regional states and thus equipped with other powers and political structures than local authorities. We excluded Paris on similar grounds - it is the sole municipality in France that is simultaneously a département. Anonymized data will be made publicly available at the GESIS Data Archive for the Social Sciences (http://www.gesis.org/en/services/data-analysis/data-archive-service/).
} 
the coding in four steps. First, a category scheme was inductively developed from the responses given. Second, to ensure intercoder reliability, two researchers independently coded the answers using the category scheme. Answers including several pertinent attributes were coded along several categories, with every distinct element of an answer being coded with one category exclusively. Third, codings were compared, unclear codings were discussed and some categories redefined. Fourth, all answers were coded with the revised categories. We understand our survey responses as capturing perceptions and cognitive orientations, the shared definitions of the social reality that, "often latently, underlie coordinated action" (Schimank 2007, 165; see also Deephouse and Suchman 2008).

\section{Perceptions of diversification and change}

Cities have traditionally been described as marked by heterogeneity. It is commonly assumed that in Western Europe such heterogeneity has increased markedly in the past few decades as a result of immigration, but also the diversification of forms of life. How do local actors perceive this situation? In the CityDiv-survey, we asked: "Would you say that your city has become more diverse in the past 20 years or, rather, that there has been little change?" Moreover, we asked respondents to specify in what respects they thought their city had become more diverse. We then coded the answers to capture which aspects of change were salient.

In both France and Germany, large majorities said their cities had become more diverse over the past two decades (81\% in French cities, 92\% in German cities). But we also see differences: While in all German cities more than $80 \%$ shared this perception, the range is broader in the French cities. In 11 out of 18 cities the respective share was $80 \%$ or more, in five cities fewer than $70 \%$ emphasized diversification.

What do local actors associate with growing diversity? In the German cities a majority of respondents (57\% of those reporting that their city had become more diverse) think of migration or ethnic and religious diversity, with shares in the individual cities ranging from $32 \%$ to $78 \%$. Among French respondents this link is much more tenuous. Only 25\% of French respondents who agree that their cities have become more diverse specifically mention aspects related to migration or ethnic and religious diversity. Much more frequently, they refer to transformations more generally, sometimes regarding transportation, physical aspects of their cities or the local economy.

It is hard to tell whether recent immigration movements inform associations of diversity with immigration. In some of Germany's big cities, the share of people with migration background in the population has increased somewhat since 2005 (when this information was first recorded). ${ }^{3}$ Refugee arrivals were increasing when this survey was conducted in Germany (for German cities, the field period ran from April to July 2015), but the so-called 'refugee crisis' was still to come. The French cities sampled experienced similarly modest increases in the share of immigrants in their population between 2006 and 2015, with an average increase of $2.5 \%{ }^{4}$

${ }^{3}$ For instance, in Dortmund and Düsseldorf, shares of those with migration backgrounds were about 3\% higher in 2015 than in 2005, going up to 30 and 34\%, while in Cologne they remained at around 30\% (Statistik NRW).

${ }^{4}$ Population statistics for cities at the Commune level drawn from official National Statistics Institute counts (INSEE). 
We know that developments are not simply salient because they occur, they need to be politicized and present in the public debate in order to be on the minds of societal actors (e.g. Lowry and Joslyn 2014). Barring important demographic changes, different political discourses are a more plausible explanation for the observed difference between the two countries than immigration. In Germany, immigrant integration policy was accorded high political priority with the immigration law of 2005, and such policies are increasingly framed as diversity policies (Schönwälder and Triadafilopoulos 2016). On the other hand, fewer references to immigration-related changes in France may be indicative of the predominance of other political and social issues or a deliberate silence about, in particular, migration-related difference (Flamant 2016).

Although the association is frequent, diversification is not seen as identical with the consequences of migration. In France, 13\% of respondents point to socio-economic diversification, such as the arrival of new middle-class people or increasing inequalities, a perspective that is almost missing in German cities (3\%). This may reflect a stronger tradition of naming and classifying differences in socio-economic terms in France. On the other hand, lifestyle differences, the presence of sexual minorities and disabled persons are aspects mentioned exclusively by German respondents (11\%). Apparently, diversity discourses that address a set of diversity dimensions have some, albeit limited, influence in Germany and seem largely unknown in France. We can interpret this as sign of a more consolidated and multi-faceted diversity discourse in Germany.

Still, the following paragraphs will show that "Vielfalt/diversite", or diversity, is a meaningful term for respondents in both countries. Having established that a great majority of local actors see their cities as diversifying - and that this development is associated with different phenomena in Germany and France - we will now have a closer look at the evaluations of the observed diversity, that is, whether diversity is perceived as beneficial or as harmful.

\section{Evaluations of diversity: beneficial or harmful for the city?}

To avoid priming respondents in favor of a specific opinion and to reduce social desirability bias, we asked about their opinions on two statements alternatively describing diversity as beneficial and as challenging. Further, we asked them to specify effects of diversity in the respondent's city ("It is nowadays often said that diversity is an opportunity. How does your city specifically profit from an increasing diversity?" and "Diversity is often perceived as a challenge or even a burden. In what ways is for your city specifically diversity (also) a burden?").

Overall, a majority of our respondents in both countries agreed on a positive evaluation of diversity and named at least one beneficial aspect for their city. This view, however, is clearly more influential among German local actors: $89 \%$ of the German respondents named at least one form in which diversity is beneficial for their city whereas only $61 \%$ of the French respondents did the same. In France, 15\% of respondents explicitly denied that diversity brings benefits for their city. This includes a small group that criticizes policies and institutions that prevent diversity from being beneficial, i.e. people whose own position towards diversity is positive. ${ }^{5}$ Such respondents criticize state responses to diversity, rather than diversity itself, a position that we will

${ }^{5}$ One respondent objects, for example: "On the contrary, it is presented as something negative. The topics of 'return migration' are adopted by the Identitarians, the mayor stigmatizes the 'travellers', persecutes the Roms, pushes the poor towards the periphery... ". 
also find in further analyses below. In contrast, among our German respondents only a small minority of $2 \%$ denied positive effects of diversity for their city. Apparently, the perception of diversity as beneficial is somewhat contested in French cities and more or less agreed upon in German cities. This finding of a stronger consensus about the positive aspects of diversity in Germany also holds when we look at the responses by cities. In only two out of 20 German cities less than $80 \%$ of the respondents mention benefits of diversity. By contrast, across the 18 French cities included in the city-level analysis the share of respondents naming benefits ranges from $27 \%$ to $90 \%$.

Turning to the counterpoint question item, the ways in which diversity is considered a challenge or even burden for the city, we find that, overall, the share of respondents suggesting that diversity is burdensome is significantly lower than that perceiving benefits. A noteworthy share of about a quarter of the local actors explicitly rejected the view that diversity is a burden (31\% of French local actors and $25 \%$ in Germany). This is even more remarkable as the survey question only suggested that diversity may also be a burden. Positive views of diversity thus clearly prevail. Interestingly, French respondents, while more sceptical regarding positive effects of diversity on their city, at the same time agree to a lesser extent than German respondents with the statement that diversity is a challenge or burden $(55 \%$ name ways in which diversity negatively impacts on the city, compared to $68 \%$ of the respondents in German cities). So while in German cities a stronger consensus exists that diversity is beneficial, it is also more common for local actors to point to burdens and challenges. In French cities, in contrast, both the view that diversity is beneficial for the city and the view that it might be burdensome find less support.

Many respondents pointed to both benefits and burdens arising from diversity. As Table 1 shows, in Germany this was the case for almost two thirds of respondents, as compared to $35 \%$ in France. In France, in contrast, nearly half of the respondents (47\%) expressed an exclusively positive or negative view (either beneficial effects or burdens for their city), compared with $28 \%$ of respondents in German cities. Clearly views are more polarized in French cities. The main difference between the two countries is the strength of an unequivocally negative position: It is hardly present in German cities but shared by one fifth of French respondents. One could assume that this reflects a stronger presence of extreme right actors. But among these respondents with an unequivocally negative position, Front National politicians are only a small group (6 respondents out of 50 overall). Those who perceive diversity solely as a burden also include representatives of leftwing and ecological parties and representatives of trade unions.

Table 1 Benefits and burdens of diversity, contrasting or combined

\begin{tabular}{lll}
\hline Respondents who & German cities & French cities \\
\hline ...mention both benefits and burdens & $64,72 \%$ & $34,9 \%$ \\
$\ldots$ mention benefits but not burdens & $24,27 \%$ & $26,5 \%$ \\
$\ldots$ mention burdens but not benefits & $3,37 \%$ & $20,1 \%$ \\
...mention no benefits and no burdens & $7,64 \%$ & $18,47 \%$ \\
\hline
\end{tabular}




\section{How do cities benefit from diversity, what is burdensome?}

Providing the possibility of open-ended answers, our survey yielded more than an evaluation of whether socio-cultural heterogeneity had positive or negative effects for the city. The concrete aspects mentioned by our respondents are indicative of specific challenges and burdens that respondents had in mind. Beginning with the benefits that were mentioned, we can isolate a set of material or utilitarian benefits, for instance for the urban economy and labour market (e.g. for attracting businesses, highly-qualified people and tourists), for the infrastructure individual residents can use (e.g. more restaurants, shopping facilities, cultural offers), for urban demography, and for science and universities (e.g. triggered by international researchers and students). Further, respondents pointed to immaterial social and cultural gains for the political culture of the city and its social and civic life (e.g. "openness", "tolerance", "living together", "intercultural activities"). Often, they broadly stated that diversity made the city more attractive, more urban, more multicultural, interesting or creative, comments we categorized as general gains for the city (Fig. 1).

German respondents frequently pointed to utilitarian benefits. Nearly half of all those naming benefits consider diversity as beneficial with regard to its economic and labour market effects, clearly more than among French respondents, where about one quarter of those naming benefits point to economic and labour market benefits. In some French cities no respondent named such benefits. Conversely, in every German city at least one quarter of respondents mentioned economic benefits, often explicitly of immigration (e.g. "skilled workers"), and in four cities more than $50 \%$ of our respondents did so. German respondents also described economic gains in more concrete, sophisticated ways. Respondents for instance pointed out that "skilled immigrants enrich the educational and enterprise sectors" and that "as science location, [the city] depends on diversity. Some service sectors cannot do without immigrants, such as care, waste collection, gastronomy". The answers of our French respondents are mostly less explicit and detailed. They mainly named benefits for more general economic developments and innovation (e.g. "new professions", "start-up", "creativity").

Among German local actors the demographic importance of diversity also features prominently, e.g. the influx of a younger population or the larger number of children in

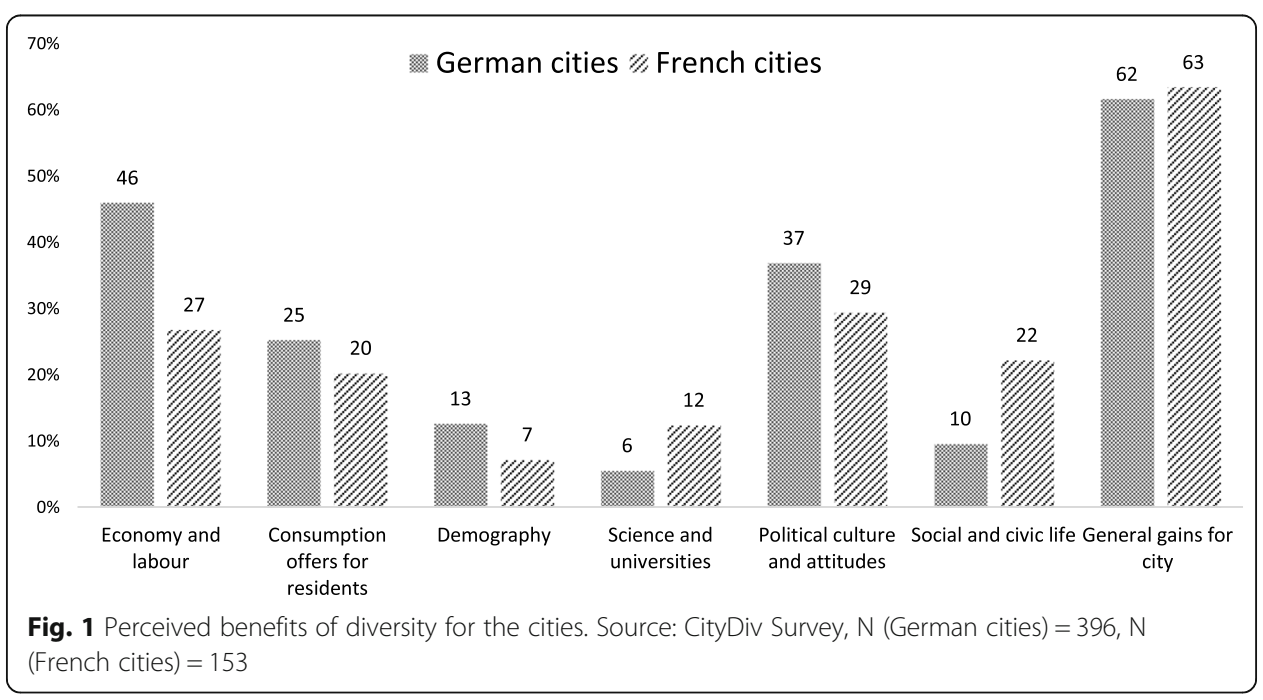


immigrant families. In French cities, this is a less important consideration. Further, German local actors more often referred to positive effects of diversity for residents' choices of goods and entertainment, mentioning e.g. that there was "more choice for residents" and "a livelier cultural scene".

Even though these findings indicate a tighter link between diversity, and specifically immigration, and economic as well as demographic benefits among respondents in German cities, we cannot reduce their perceptions of diversity benefits merely to materialistic/ utilitarian considerations (see also Moutselos et al 2018). A perception of diversity as benefitting the political culture and attitudes in the city is also prominent (37\% of the respondents naming benefits). Respondents pointed to aspects such as "openness to the world" and "tolerance", or described diversity as countering racism and right-wing mobilization.

French local actors to a lesser extent located benefits of diversity in tangible economic-material gains. They accorded greater weight to positive effects of diversity on the social and more particularly the civic life of their cities (22\% compared with $10 \%$ of German actors). French respondents, for instance, pointed to the "dynamism diversity brings to civil society", the "emergence of networks of mutual support and social cohesion", the "multiplication of associations active for the communal life", and the "richness of exchanges and initiatives".

Turning to the ways in which diversity is perceived as a challenge or burden for the city, we identify on the one hand perceptions of diversity itself, often immigration, as burdensome: for the welfare state, public services and resources (e.g. housing and schools), and for security. Sometimes characteristics of minorities are seen as presenting burdens. On the other hand, respondents criticized existing institutions as inadequate for dealing with diversity, attacked prejudiced or racist attitudes in the population, or pointed to socio-economic inequalities as the actual problem. In this second type of answers respondents do not blame those representing a new diversity but existing structures and attitudes that fail to accommodate diversity adequately. Thus, actors who see challenges do not necessarily perceive diversity as causing them. In addition, we find unspecific references to problems of social cohesion and spatial segregation. The challenges and burdens of diversity are in both countries more often explicitly associated with immigration than the benefits (Fig. 2).

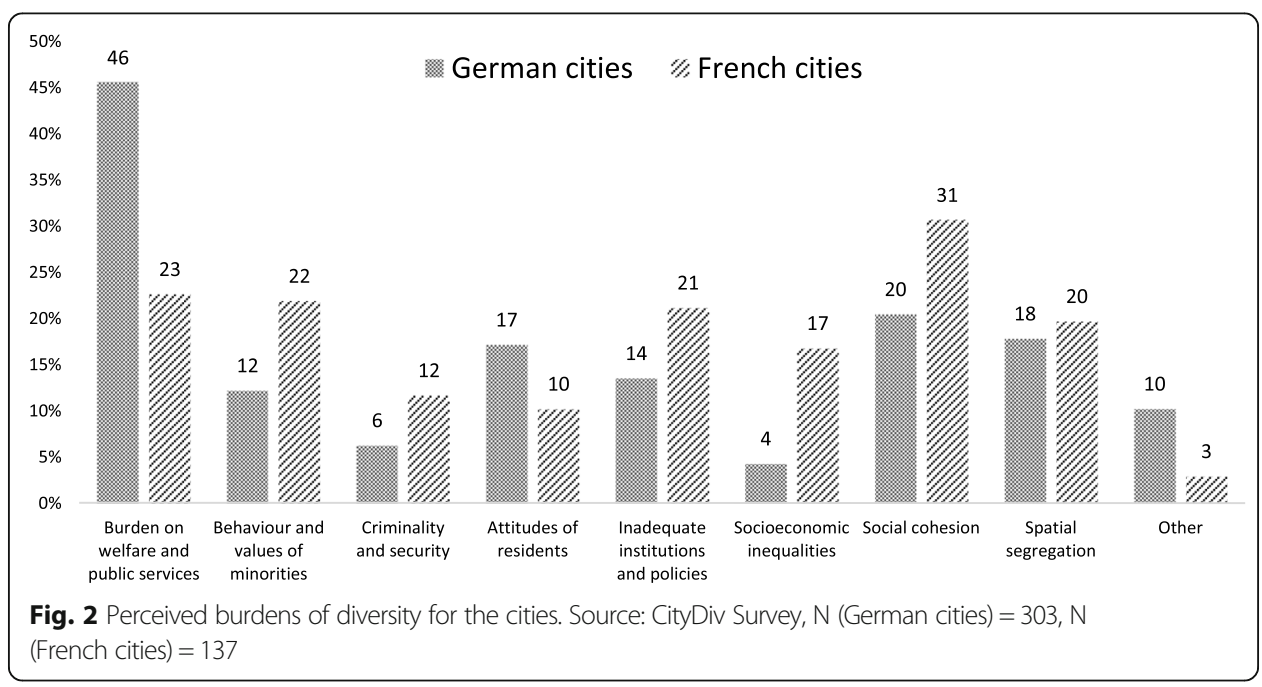


Beyond these general observations, we find that perceptions of the main challenges accompanying diversity differ between the two countries. The share of actors perceiving a burden to welfare state provisions, public services and resources is twice as high in German as in French cities. German respondents for instance mentioned "costs for refugee accommodation, cost for language acquisition and integration" or that the "increasing share of migrants poses challenges for schools and day-care centres". However, only about a third of those mentioning burdens related to migration explicitly referred to refugees, indicating that the 'refugee crisis' was not predominant in our respondents' perceptions at the time of the survey. French respondents, in contrast, more often mentioned burdens for communal life. This includes references to problems of social cohesion and societal mixing. And French actors also more often associated diversity with problems of insecurity and criminality. Further, they sometimes blamed characteristics and behaviour of minority residents. Even if we disregard the extreme-right politicians included in the French group, the respective share remains higher in French than in German cities. Quite often, French respondents refer to communautarisme as a burden, a term used in French discourse to problematize visible expressions of cultural, religious etc. differences and minority demands for recognition as contradicting French republican values and jeopardizing societal integration. This perspective is illustrated in the following quote by one of our respondents: "Diversity is a burden if it brings with it another culture or religion that defies the laws of our republic - because our ancestors fought for just causes".

As mentioned above, some respondents identified reactions to diversity - and not diversity itself - as inflicting burdens. German and French respondents differ in what they criticize. German respondents more often mentioned hostile attitudes and behaviour of non-minority residents (17\% compared with $10 \%$ of French actors). One respondent, for instance, pointed to aggressive reactions to diversity and added: "They are the burden, not diversity." Several respondents referred here to the rise of new antiimmigration and anti-Muslim movements. Shortly before the survey underlying this study was conducted, many German cities had seen demonstrations, often led by the mayors, against new anti-immigrant and anti-Muslim rallies. ${ }^{6}$ French respondents, in contrast, more often pointed to inadequate institutions as the culprits (21\% compared with $14 \%$ of German actors). Criticism of the state, as noted above already, is apparently more prominent in French cities. For example, one respondent stated: "Diversity itself is not a burden but rather a richness. It is a burden that public subsidies diminish which makes it impossible to build connections. We are asked to work better with less." Further, French respondents pointed to general socio-economic inequalities much more often, such as "pauperisation", "precarity" or the "lack of jobs which leaves people behind". Here, it is unclear whether respondents thought of migration at all or rather referred to the diversity of income and standards of living. As already pointed out, socio-economic divisions were more salient for the French than the German respondents. The following section will summarize our findings.

${ }^{6}$ For instance in Hannover under the slogan "Colourful not brown" ("Bunt statt braun") on 13 January 2015, in Bielefeld on 19 January 2015. 


\section{Common features and national differences}

Overall, our analysis identified similarities and differences in the ways German and French local actors perceive and evaluate socio-cultural heterogeneity, or diversity. In both Germany and France socio-cultural heterogeneity is widely recognized as marking contemporary cities. As expected, the trend in political debates in Germany and France of emphasizing Vielfalt/diversité is reflected in local actors' perceptions. Second, a majority of local actors emphasize positive effects of diversity on their cities. This is remarkable given the contested nature of, in particular, immigration-related diversity. Fundamental objections to diversity as, e.g., undermining the cultural or social integrity of the national or local community are not predominant among key local actors in either country. One might have expected that the long-term presence and relative strength of the extreme right, in particular in France, would have a stronger impact. In the big cities of Germany and France, diversity is widely recognized and often appreciated.

Looking at the more specific evaluations of diversity, we observe that French local actors place more emphasis on the development of social and civic life than German actors, both when considering problematic and beneficial aspects of diversity. Further, as mentioned above, in French cities, worries about threats to social cohesion, conflicts, and deviant behaviour of minorities are voiced more often, which may reflect the republican rejection of communautarisme. But the positive aspects of diversity for civic life are also stressed more often.

For German local actors, material aspects of diversity are more salient. While they more often address burdens for welfare state institutions or housing provision, they also widely recognize economic and to some extent demographic gains of diversity. While this is not in itself surprising, it is worth noting that this view is also widely shared in national discussions about immigration and diversity. Openness to diversity is often linked with the economic success of export-oriented Germany. As, for instance, the Federal President stressed in 2010, "Germany - with its connections to all parts of the world - has to be open towards those who come to us from all parts of the world" (Wulff 2010). Demographic needs contributed to a political re-orientation towards more openness to much-needed new immigration (combined with often restrictionist refugee policy) and a more inclusive and tolerant approach within German society. The linkage of diversity with the economic well-being of the country and of individual cities provides a basis for its generally positive perception.

Altogether, conceptualisations of diversity, and views as to its benefits and challenges, vary between the two countries. While in French cities diversité is not a taboo, a positive diversity discourse is not universally shared by local actors. Moreover, we observe a more pronounced polarization of either clearly positive or unambiguously negative perceptions of diversity than in German cities. Local actors in German cities to a greater extent agree on the meaning of diversity and its positive perception. Such differences and the commonalities across French and, respectively, German cities - point to a strong influence of national debates and policy paradigms.

\section{Conclusion}

This article set out to explore to what extent two major European immigrant societies have departed from past imaginaries of national homogeneity. While scholarly attention has often focused on the diffusion of assimilationist trends in countries declaring their 
departure from former multiculturalism, we investigated a contrasting trend. Countries that traditionally emphasized the homogeneity of their citizenry nowadays acknowledge socio-cultural diversification. As we could show, socio-cultural heterogeneity has become widely recognized and is often positively connoted by societal actors in German and French cities. Diversity, as explicit diversité/Vielfalt policy conceptions or as more general acknowledgement of heterogeneity, has relevance beyond selected statements of leading politicians and beyond business campaigns. In big cities, where heterogeneity is most pronounced, major societal actors address this reality and its consequences and accept it as characterizing present-day society. Our analysis focused on patterns distinguishing French and German cities, leaving aside differences between the cities in each country (for a comparison across cities see Martínez-Ariño et al 2018). Given the empirical basis used in this article, findings cannot claim to represent social realities in France and Germany comprehensively. While we investigated big city realities more broadly than many other studies, we cannot tell whether our findings may be replicated in small towns or rural areas. Here, populations structures are different, and further research should explore to what extent such local realities shape perceptions. However, for important actors in the 40 largest cities of the two countries, we could show to what extent observations made so far for national policy debates apply more widely across society.

Indeed, evaluations of diversification and the degree of consensus over this differ between the national contexts. This observation does not lead us back to the 'grand narrative' of national philosophies of immigrant incorporation. National policy orientations and traditions play an important role in shaping local perceptions, but influences are complex and do not boil down to the concept of the nation. In France, as our analysis shows, worries about threats to social cohesion, conflicts, and deviant behavior of minorities are more common than among German local actors. Repeated controversies about visible expressions of religious, especially Muslim, identifications in public space, in particular in France, illustrate the extent to which recognition of differences is contested and continuously reproduce anxiety about cultural difference. In France, recognition of difference was and still is a delicate issue (Bertossi 2016; Simon 2013). As suggested above, the much-cited influence of "republican" conceptions of equal citizens does not fully account for such contestation.

Stronger polarization among French local actors can be interpreted as a result of specific political developments. The strong identification of the political Right under president Sarkozy with the notion of diversité contributed to a growing opposition on the Left against the concept. Left-wing party politicians and NGO representatives criticize explicit diversité concepts for failing to address structural inequalities and racial discrimination (Doytcheva 2015, 52-3; Bereni 2009). Sometimes, diversity is seen as a concept that makes equality conditional on individual performance, a neoliberal logic incompatible with demands for equality (Sénac 2012, 260-1; see also Bereni 2009). Furthermore, as Lépinard (2013, 284-5) argues, the successful movement for gender equality (parité) hindered, rather than helped the popularity of diversité in France. In seeking to win popular support, feminists defined their cause as in line with the French republican tradition and in the name of humanity, not difference. Given this tradition and the association of diversité with the political Right, broad alliances for a recognition of diversity are unlikely. The strong emphasis on the social question and class struggles in the French political culture presents another obstacle for a wider acceptance of diversity policy conceptions in 
particular by the Left (Wieviorka 2010, 252; see also Dressler et al. 2012). As demonstrated above, socio-economic cleavages as dimensions or consequences of diversity are salient almost exclusively in French cities. A tradition of social criticism and classoriented perspectives exerts a noticeable influence here - but not among German local actors. Thus, there is a contested process of sense-making and a more confrontational political constellation in France. Furthermore, several scholars have claimed that the desire to address difference in politics has recently given way to a renewed predilection for cohesion. This trend may also contribute to the polarization found in our data.

The findings for Germany reflect a broad political consensus regarding the appreciation of diversity (see also Martínez-Ariño et al 2018). Here, long-term supporters of liberal immigration policies and multiculturalism - rather than resenting the identification of the Conservative Party with diversity - tend to be glad that, at last, immigration is accepted as a social fact and the long struggle about Germany's character as an immigration country seems won. Commitments to Vielfalt have a different meaning than in France. They are more clearly associated with a departure from former conceptions of the national citizenry.

It also helped that, in Germany, diversity declarations and programmes typically went along with a re-definition of the problem of immigrant integration as one of ensuring participation on an equal footing (gleichberechtigte Teilhabe), especially in the spheres of education and the labour market (e.g. Beauftragte 2012). This resonates with traditional demands of social democrats and trade unions who can thus identify with such concepts. Criticism of diversity policy conceptions as parts of a neo-liberal and individualist agenda helping to obscure structures of unequal power and discrimination is present in the German debate but has a more limited impact than in France. Vielfalt in the German context has also become a symbolic reference uniting those opposing the populist and extreme right. At the same time, German local actors do not hold exclusively positive views and do not ignore potential problems. It is even more common for German than for French local actors to mention challenges or burdens associated with diversity. However, in German cities the belief that diversity, often associated with immigration, presents burdens does not undermine a generally positive evaluation.

In Germany, a long-term rejection of immigration and its consequences has given way to a programmatic commitment to Vielfalt and a selective and contested openness to immigration. The widely recognized economic and demographic need for immigration contributes to a relative consensus over the benefits of diversity. In France, developments are more equivocal. Altogether, recognition and interpretation of heterogeneity remain more contested. Appeals to republican ideas of society, and thus the uniformity of the citizenry, remain influential, while diversity is also widely acknowledged. Altogether, conceptualisations of diversity play a different role in the two countries; diversity has a different function in debates about immigration and its consequences.

Ideas provide the cognitive roadmap, appropriate categories, models, and basis of legitimacy for concrete actions. Our analysis suggests that, in German cities, there exists a shared willingness among local actors to treat processes of diversification as altogether positive changes to urban society. Such an optimistic consensus can provide the ground for both widely supported policy responses and for resistance against a growing antidiversity mobilization. In French cities, the more ambiguous and polarized picture suggests that political responses across cities will be more varied and contested and that affirmation of diversity will play a weaker role in mobilizations against the extreme right. 


\section{Supplementary information}

Supplementary information accompanies this paper at https://doi.org/10.1186/s40878-020-00205-1.

\section{Additional file 1.}

\section{Acknowledgements}

Dr. Julia Martínez-Ariño, Dr. Alexandre Tandé, Christian Jacobs.

\section{Authors' contributions}

Maria Schiller, Christine Lang, Karen Schönwälder and Michalis Moutselos have contributed to this article. The author(s) read and approved the final manuscript.

\section{Funding}

The research for this article was kindly funded by the Max Planck Institute for the Study of Religious and Ethnic Diversity, Göttingen, Germany.

\section{Availability of data and materials}

The data and material is currently not yet publically available.

\section{Competing interests}

We don't have any competing interests to declare.

\section{Author details}

${ }^{1}$ Erasmus University Rotterdam, Rotterdam, The Netherlands. ${ }^{2}$ Max Planck Institute for the Study of Religious and Ethnic Diversity, Göttingen, Germany.

Received: 9 August 2019 Accepted: 21 September 2020

Published online: 15 December 2020

\section{References}

Alba, R., \& Foner, N. (2014). Comparing immigrant integration in North America and Western Europe: How much do the grand narratives tell us? International Migration Review, 48(1), 263-S291.

Avanza, M. (2010). Qui représentent les élus de la 'diversité'? Revue Française de Science Politique, 60(4), 745-767.

Beauftragte (2012). 9. Bericht der Beauftragten der Bundesregierung für Migration, Flüchtlinge und Integration über die Lage der Ausländerinnen und Ausländer in Deutschland. Berlin: https://www.bundesregierung.de/Content/DE/_Anlagen/IB/201206-27-neunter-lagebericht.pdf?_blob=publicationFile. Accessed 30 July 2018.

Bereni, L. (2009). Faire de la diversité une richesse pour l'entreprise. Raisons politiques, 35(3), 87-105.

Bereni, L., \& Epstein, R. (2015). Instrumenter la lutte contre les discriminations: Le "label diversité" dans les collectivités territoriales. Rapport de recherche. Nantes: CNRS Centre Maurice Halbwachs and Université de Nantes https://halshs.archives-ouvertes. fr/halshs-01156953/document. Accessed 30 July 2018.

Bereni, L., Epstein, R., \& Torres, M. (2020). Colour-blind diversity: How the "diversity label" reshaped anti-discrimination policies in three French local governments. Ethnic and Racial Studies Online First. 43(11), 1942-1960.

Bertossi, C. (2016). La citoyenneté à la française. Valeur et réalités. Paris: CNRS Éditions.

Bleich, E. (2002). Integrating ideas into policy-making analysis. Frames and race policies in Britain and France. Comparative Political Studies, 35(9), 1054-1076.

Borevi, K., Kriegbaum Jensen, K., \& Mouritsen, P. (2017). The civic turn of immigrant integration policies in the Scandinavian welfare states. Comparative Migration Studies, 5(9), 1-14.

Bos, L., Lecheler, S., Mewafi, M., \& Vliegenthart, R. (2016). It's the frame that matters: Immigrant integration and media framing effects in the Netherlands. International Journal of Intercultural Relations, 55, 97-108.

Boswell, C., \& Hampshire, J. (2017). Ideas and agency in immigration policy: A discursive institutionalist approach. European Journal of Political Research, 56(1), 133-150.

Bundesregierung. 2007. Newsletter der Kampagne "Vielfalt als Chance". www.bundesregierung.de

City of Cologne (2011). Konzept zur Stärkung der integrativen Stadtgesellschaft. Köln.

City of Nürnberg (2018). Integrationspolitik der Stadt Nürnberg. Nürnberg: City of Nürnberg.

Deephouse, D. L., \& Suchman, M. (2008). Legitimacy in organizational institutionalism. In R. Greenwood, C. Oliver, R. Suddaby, \& K. Sahlin (Eds.), The sage handbook of organizational institutionalism, (pp. 49-77). London: Sage.

Doytcheva, M. (2015). Politiques de la diversité. Sociologie des discriminations et des politiques antidiscriminatoires au travail. Brussels: Peter Lang.

Dressler, W., Sicakkan, H. G., Fuga, A., Mitroi, V., \& Terrazzoni, L. (2012). The French republican model, the European diversity perspective and the European public sphere. Social Science Information, 51(3), 418-447.

Emilsson, H. (2015). A national turn of local integration policy: Multi-level governance dynamics in Denmark and Sweden. Comparative Migration Studies, 3(7), 1-16.

Entman, R. M. (1993). Framing: Toward clarification of a fractured paradigm. Journal of Communication, 43(4), 51-58

Escafré-Dublet, A., \& Simon, P. (2009). Représenter la diversité en politique: une reformulation de la dialectique de la difference et de l'égalité par la doxa républicaine. Raison politiques, 35(3), 125-141.

Flamant, A. (2014). Droit de cité! Construction et dilution d'une politique municipale d' "intégration des étrangers" dans les villes de Lyon, Nantes et Strasbourg (1981-2012). Unpublished PhD thesis. Lyon: Université de Lyon.

Flamant, A. (2016). Donner la parole aux étrangers? De la création d'une participation politique à l'usage ethnicisé de la catégorie d' "étranger" par les municipalités. Participations, 14(1), 237-264.

Früh, W. (2015). Inhaltsanalyse: Theorie und praxis, (8th ed., ). Konstanz: UVK. 
Glasze, G., \& Meyer, A. (2009). Das Konzept der 'kulturellen Vielfalt': Protektionismus oder Schutz vor kultureller Homogenisierung? In J. Kessler, \& C. Steiner (Eds.), Facetten der Globalisierung, (pp. 186-197). Wiesbaden: Springer VS. Helbling, M. (2014). Framing immigration in Western Europe. Journal of Ethnic and Migration Studies, 40(1), 21-41.

Hellwig, T., \& Sinno, A. (2017). Different groups, different threats: Public attitudes towards immigrants. Journal of Ethnic and Migration Studies, 43(3), 339-358.

King, D. S., \& Smith, R. M. (2014). 'Without regard to race': Critical ideational development in modern American politics. The Journal of Politics, 76(4), 958-971.

Lelévrier, C., Rivière, C., Escafré-Dublet, A., \& Shokry, G. (2017). DIVERCITIES: Dealing with urban diversity. The case of Paris. Utrecht: Utrecht University.

Lépinard, É. (2013). For women only? Gender quotas and intersectionality in France. Politics and Gender, 9(3), 276-298.

Lowry, W. R., \& Joslyn, M. (2014). The determinants of salience of energy issues. Review of Policy Research, 31(3), 153-172.

Martínez-Ariño, J. (2017). Conceptualising the role of cities in the governance of religious diversity in Europe. Current Sociology, 1(18), 1-18.

Martínez-Ariño, J., Jacobs, C., Moutselos, M., Schönwälder, K., Schiller, M. \& Tandé, A. (2018). Why do some cities adopt more diversity policies than others? a study in France and Germany. Comparative. European Politics, 17, 1-22.

Moutselos, M., Jacobs, C., Martiń ez-Ariño J., Schiller, M., Schönwälder, K., Tandé, A. (2017). Cities and the Challenge of Diversity (CityDiv): The Survey, Technical Report. MMG Working Paper, 17-09, Max Planck Institute for the Study of Religious and Ethnic Diversity, Göttingen.

Moutselos M, Jacobs C, Martínez-Ariño J, Schiller M, Schönwälder K, Tandé A. (2018) Economy or Justice? How urban actors respond to diversity. Urban Affairs Review, 56(1), 228-253.

Poppelaars, C., \& Scholten, P. (2008). Two worlds apart: The divergence of national and local immigrant integration policies in the Netherlands. Administration and Society, 40(4), 335-357.

Pütz, R., \& Rodatz, M. (2013). Kommunale Integrations- und Vielfaltskonzepte im Neoliberalismus. Zur strategischen Steuerung von Integration in deutschen Großstädten. Geographische Zeitschrift, 101(3-4), 166-183.

Sabbagh, D. (2011). Affirmative action: The U.S. experience in comparative perspective. Daedalus, 140(2), 109-120.

Scharpf, F. W. (1997). Games real actors play. Actor-centered institutionalism in policy research. Boulder: Westview Press.

Schiller, M. (2016). European cities, municipal organizations and diversity: The new politics of difference. Basingstoke: Palgrave Macmillan.

Schimank, U. (2007). Neoinstitutionalismus. In A. Benz, S. Lütz, U. Schimank, \& G. Simonis (Eds.), Handbuch Governance. Theoretische Grundlagen und empirische Anwendungsfelder, (pp. 191-175). Wiesbaden: VS Verlag für Sozialwissenschaften.

Schmidt, V. A. (2008). Discursive institutionalism: The explanatory power of ideas and discourse. Annual Review of Political Science, $11(1), 303-326$.

Scholten, P. (2011). Framing immigrant integration. Dutch research-policy dialogues in comparative perspective. Amsterdam: Amsterdam University Press.

Schönwälder, K., \& Triadafilopoulos, T. (2016). The new differentialism: Responses to immigrant diversity in Germany. German Politics, 25(3), 366-380.

Sénac, R. (2012). L'invention de la diversité. Paris: Presses Universitaires de France.

Simon, P. (2013). Contested citizenship in France: The republican politics of identity and integration. In A. Cola, S. Meunier, \& V. Tiberj (Eds.), Vol. 5 of Developments in French politics, (pp. 203-217). Basingstoke: Palgrave Macmillan.

Stoker, G. (2000). Urban political science and the challenge of urban governance. In J. Pierre (Ed.), Debating governance: Authority, steering, and democracy, (pp. 91-109). Oxford: Oxford University Press.

Tucci, I. (2011). Immigration, intégration et diversité en France et en Allemagne. Informations sociales, 163(1), 116-123.

Vertovec, S., \& Wessendorf, S. (Eds.) (2010). The multiculturalism backlash. European discourses, policies and practices. New York: Routledge.

Volkert, D. (2017). Parteien und Migranten: Inkorporationsprozesse innerhalb der SPD und der französischen PS. Bielefeld: Transcript.

Weber, F. D. (2013). Soziale Stadt - Politique de la Ville - Politische Logiken. Wiesbaden: Springer VS.

Weber, R. P. (1990). Basic content analysis. Newbury Park: Sage.

Wieviorka, M. (2010). 18. Questions sur la 'diversité'. In A. Mbembe, F. Vergès, F. Bernault, A. Boubeker, N. Bancel, \& P. Blanchard (Eds.), Ruptures postcoloniales, (pp. 249-255). Paris: La Découverte.

Wulff, C. 2010. "Vielfalt schätzen - Zusammenhalt fördern". Rede von Bundespräsident Christian Wulff zum 20. Jahrestag der Deutschen Einheit in Bremen am 3. Oktober 2010. http://www.bundespraesident.de/SharedDocs/Reden/DE/ChristianWulff/Reden/2010/10/20101003_Rede.html. Accessed 30 July 2018.

\section{Publisher's Note}

Springer Nature remains neutral with regard to jurisdictional claims in published maps and institutional affiliations. 